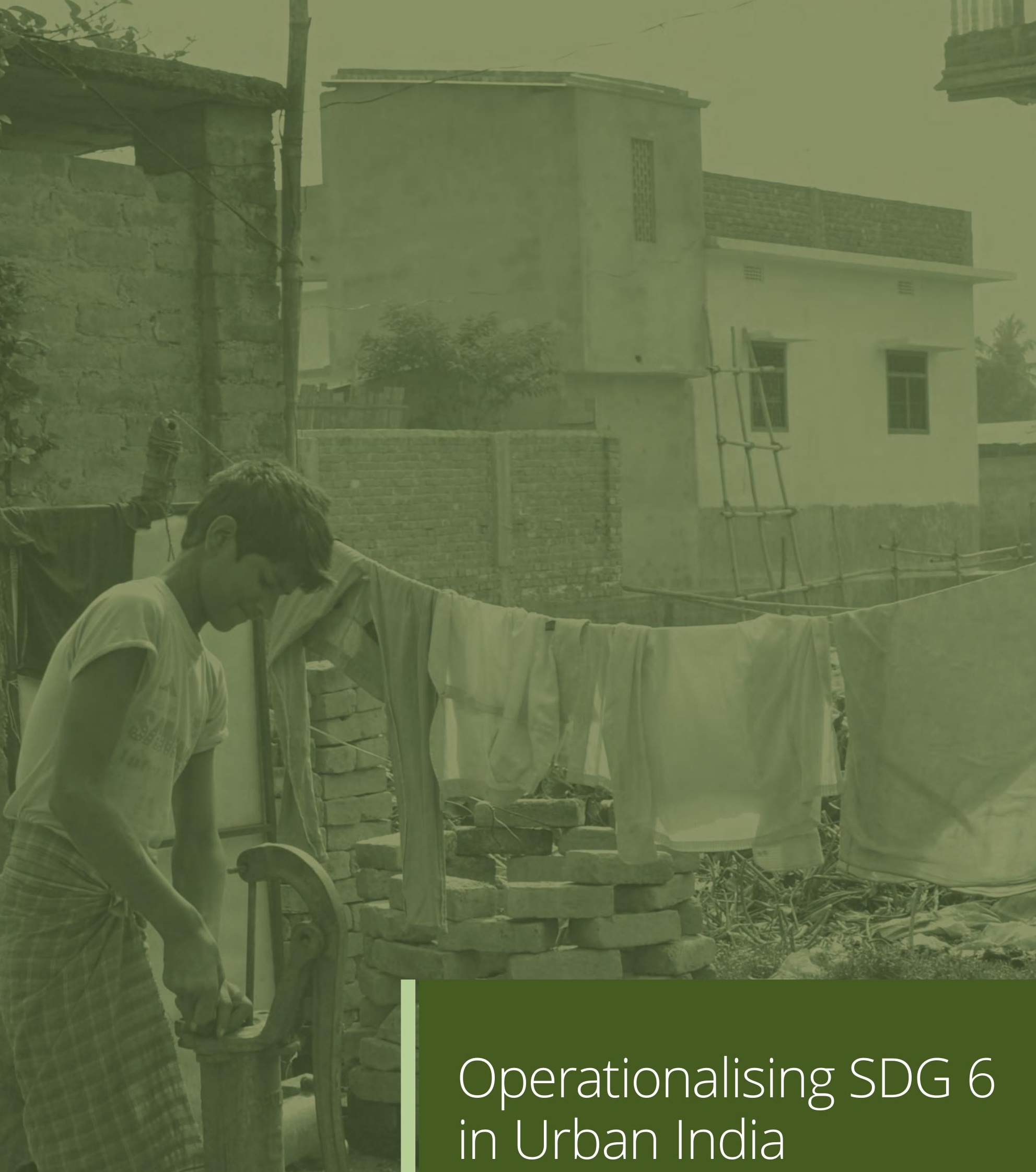

\title{
Kavita Wankhade
}

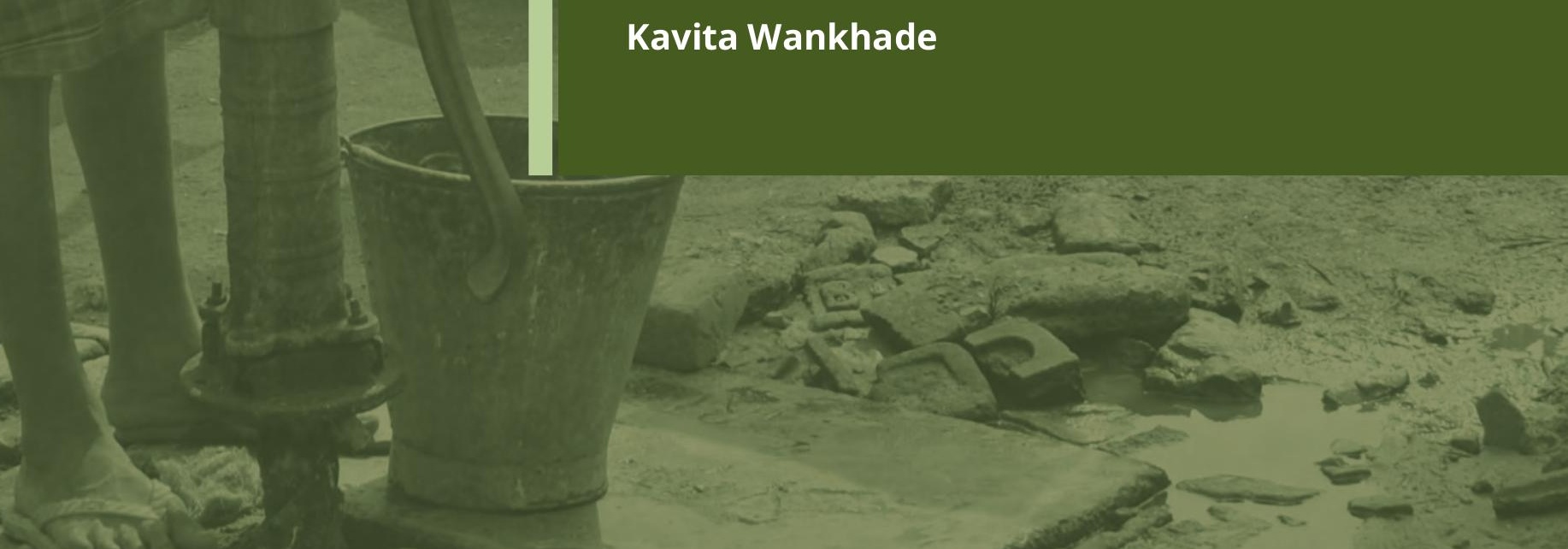





\section{Operationalising SDG 6 in Urban India}

Goal 6 of the Sustainable Development Goals (SDGs) is to 'ensure availability and sustainable management of water and sanitation for all', with specific targets for universal access to safe drinking water and sanitation facilities, enhancing water efficiency, improvement of water quality, integrated water resources management and restoration of water-related ecosystems.

\section{GOAL 6: Ensure availability and sustainable management of water and sanitation for all}

6.1: By 2030, achieve universal and equitable access to safe and affordable drinking water for all

6.2: By 2030, achieve access to adequate and equitable sanitation and hygiene for all and end open defecation, paying special attention to the needs of women and girls and those in vulnerable situations

6.3: By 2030, improve water quality by reducing pollution, eliminating dumping and minimizing release of hazardous chemicals and materials, halving the proportion of untreated wastewater and substantially increasing recycling and safe reuse globally

6.4: By 2030, substantially increase water-use efficiency across all sectors and ensure sustainable withdrawals and supply of freshwater to address water scarcity and substantially reduce the number of people suffering from water scarcity

6.5: By 2030, implement integrated water resources management at all levels, including through transboundary cooperation as appropriate

6.6: By 2020, protect and restore water-related ecosystems, including mountains, forests, wetlands, rivers, aquifers and lakes

This commentary begins with an overview of the progress made on the Millennium Development Goals (MDGs) for 2015, with regard to drinking water and sanitation in urban India. It situates the barriers and opportunities for achieving SDGs 2030 using India's policy and programmes, and outlines a framework for measuring progress along with institutional and financing mechanisms. 


\section{Progress on MDGs}

The global target for water and sanitation under the MDGs was to reduce by half, the proportion of population without sustainable access to safe drinking water and basic sanitation, by 2015.

\section{Drinking Water}

Both rural and urban India have met the MDG targets for improved drinking water, and reduced by more than half, the percentage of population with access to improved drinking water, ${ }^{1}$ as presented in Table 1. However, the robustness of these achievements needs to be qualified. In the Indian context, availability of physical infrastructure at the household level does not indicate adequate supply of water of acceptable quality. Hence, households may have access to an 'improved' source but this could be infructuous. The difficulties arising from the gap between these definitions and their interpretation for urban India are presented in a later section.

\begin{tabular}{|c|c|c|c|c|c|c|c|c|c|c|c|c|c|c|c|c|}
\hline & \multicolumn{5}{|c|}{ URBAN } & \multicolumn{5}{|c|}{ RURAL } & \multicolumn{5}{|c|}{ TOTAL } & \multirow{3}{*}{$\begin{array}{l}\text { Percentage } \\
\text { of } \\
\text { population } \\
\text { that gained } \\
\text { access since } \\
1990\end{array}$} \\
\hline & \multicolumn{3}{|c|}{ Improved } & \multirow[b]{2}{*}{ 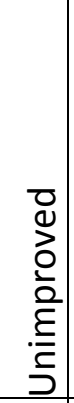 } & \multirow[b]{2}{*}{ 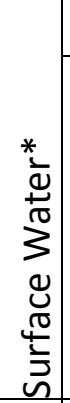 } & \multicolumn{3}{|c|}{ Improved } & \multirow[b]{2}{*}{ 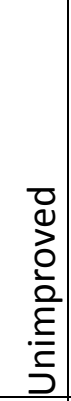 } & \multirow[b]{2}{*}{ 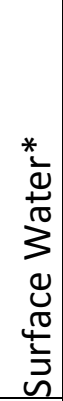 } & \multicolumn{3}{|c|}{ Improved } & \multirow[b]{2}{*}{ 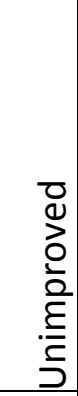 } & \multirow[b]{2}{*}{ 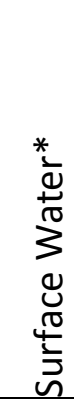 } & \\
\hline Year & 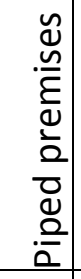 & 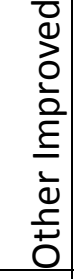 & $\begin{array}{l}\overline{0} \\
0 \\
0 \\
\overline{0} \\
\underline{E} \\
\bar{T} \\
\stackrel{0}{0} \\
\end{array}$ & & & 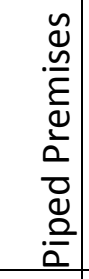 & 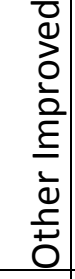 & 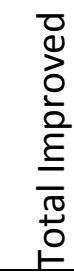 & & & 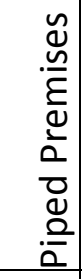 & 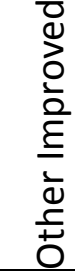 & $\begin{array}{l}0 \\
d \\
0 \\
0 \\
\frac{0}{\varepsilon} \\
\underline{\underline{\varepsilon}} \\
\frac{\pi}{0} \\
0 \\
\end{array}$ & & & \\
\hline 1990 & 47 & 42 & 89 & 10 & 1 & 6 & 58 & 64 & 32 & 4 & 16 & 55 & 71 & 26 & 3 & \\
\hline 2015 & 54 & 43 & 97 & 3 & 0 & 16 & 77 & 93 & 6 & 1 & 28 & 66 & 94 & 5 & 1 & 46 \\
\hline
\end{tabular}

Source: JMP, UNICEF-WHO, 2015

Note: Surface water is considered 'unimproved' and features at the bottom of the water ladder; hence it is reported in a disaggregated manner.

\footnotetext{
${ }^{1}$ A Joint Monitoring Programme (JMP) was set up by WHO-UNICEF to monitor progress for water and sanitation. According to the JMP, an 'improved' drinking water source is one that, by the nature of its construction and when properly used, adequately protects the source from outside contamination, particularly faecal matter. 'Improved' drinking water sources include: piped water into dwelling, public taps or standpipes, tube wells or boreholes, protected dug wells, protected springs and rainwater collection. 'Unimproved' sources include unprotected spring, unprotected dug well, cart with small tank/drum, tanker-truck, surface water and bottled water.
} 


\section{Sanitation}

Table 2 highlights that India, particularly rural India, fell short of achieving the MDG targets for improved sanitation. ${ }^{2}$ While urban India succeeded in meeting the target by halving the prevalence of open defecation (from 29 per cent to 10 per cent), India did not manage to meet the overall target for improved sanitation. This was mainly on account of shared toilets being classified as 'unimproved'.

\section{Table 2: Improvements in Access to Improved Sanitation in India, 1990-2015 (Percentage)}

\begin{tabular}{|c|c|c|c|c|c|c|c|c|c|c|c|c|c|}
\hline & \multicolumn{4}{|c|}{ URBAN } & \multicolumn{4}{|c|}{ RURAL } & \multicolumn{4}{|c|}{ TOTAL } & \multirow[b]{3}{*}{$\begin{array}{c}\text { Percentage of } \\
\text { population that } \\
\text { gained accessed } \\
\text { since } 1990\end{array}$} \\
\hline & \multirow[b]{2}{*}{ 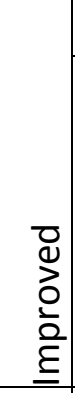 } & \multicolumn{3}{|c|}{ Unimproved } & \multirow[b]{2}{*}{ 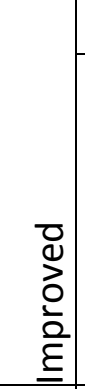 } & \multicolumn{3}{|c|}{ Unimproved } & \multicolumn{4}{|c|}{ Unimproved } & \\
\hline Year & & $\begin{array}{l}\frac{0}{d} \\
\frac{d}{\pi} \\
\frac{\tau}{n}\end{array}$ & 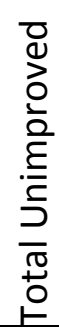 & 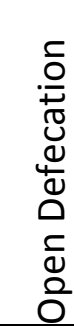 & & $\begin{array}{l}\frac{D}{d} \\
\frac{d}{\sigma} \\
\frac{c}{n}\end{array}$ & 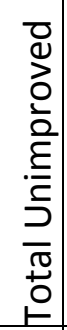 & 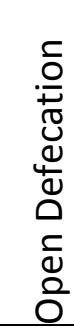 & 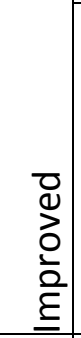 & $\begin{array}{l}\frac{0}{d} \\
\frac{d}{\sigma} \\
\frac{\tau}{n} \\
\end{array}$ & 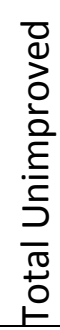 & 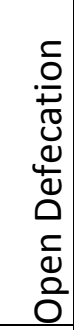 & \\
\hline 1990 & 49 & 16 & 6 & 29 & 6 & 1 & 2 & 91 & 17 & 5 & 3 & 75 & \\
\hline 2015 & 63 & 21 & 6 & 10 & 28 & 5 & 6 & 61 & 40 & 10 & 6 & 44 & \\
\hline
\end{tabular}

Source: JMP, UNICEF-WHO, 2015

During the MDG time frame (1990 to 2015), the primary investments for urban water and sanitation in urban India were made through the Jawaharlal Nehru National Urban Renewal Mission (JNNURM). ${ }^{3}$ While JNNURM prioritised universal coverage, it did not set a target date to achieve this (for either water or sanitation/sewerage). JNNURM did not have any provision for individual toilets, and most of the investments were dedicated to the piecemeal construction of pipes and treatment systems.

While the MDGs prioritised access to water and sanitation, the two major deficits were as follows:

1. The definition of access was narrow and measured the physical arrangements (e.g., water taps) available in households. Service levels, for instance, hours of water supply, were not taken into account.

2. The scope did not include the complete chain of water supply (source to adequate quality and service levels) and sanitation (safe containment, conveyance, and disposal after treatment).

2 JMP defines 'improved' sanitation to include: flush/pour flush to piped sewer system, or septic tank, or pit latrine; Ventilated improved pit (VIP) latrine, pit latrine with slab and composing toilet. 'Unimproved' options include: flush/pour flush to elsewhere, pit latrine without slab, bucket latrine, hanging latrine, shared sanitation and no facilities or open defecation.

${ }^{3}$ JNNURM was implemented in 68 selected cities, from 2005 to 2015. It consolidated erstwhile smaller investments in urban water and sanitation, including the Accelerated Urban Water Supply Programme, etc. 


\section{Unpacking SDG 6: How is urban India doing?}

The targets for water and sanitation as articulated in Goal 6 of the SDGs mark a substantial move forward from those articulated in the MDGs. 'Water and Sanitation' is a distinct goal in itself, instead of being nested as a target within another goal. SDG 6 moves beyond the singular focus of the MDGs on access (to water and sanitation), and attempts to widen its scope by looking at the entire cycle of water and sanitation. In terms of access, it has set a much more ambitious target of universal access to both water and sanitation. Table 3 presents key comparisons across the MDGs and SDGs.

\begin{tabular}{|c|c|c|c|}
\hline No. & Parameter & MDG & SDG \\
\hline 1 & Scope & Access to water and sanitation & $\begin{array}{l}\text { Access to water and sanitation } \\
\text { Improvement in water quality } \\
\text { Improvement in water efficiency } \\
\text { Integrated water resources management }\end{array}$ \\
\hline 2 & Target & $\begin{array}{l}\text { Halve the number of people } \\
\text { without access to water and } \\
\text { sanitation } \\
\text { No other targets }\end{array}$ & $\begin{array}{l}\text { Universal Coverage for access to both } \\
\text { water and sanitation, i.e. } 100 \% \\
\text { Reducing by half, the proportion of } \\
\text { untreated waste water } \\
\text { Recycling, improvements in water } \\
\text { efficiency (targets not specified) }\end{array}$ \\
\hline
\end{tabular}

An appreciation of urban India's current standing with respect to the SDGs will depend upon how we choose to define and interpret the SDG targets. Let us examine each of the targets, lay out the measurement framework, and then assess where we stand.

\section{1: By 2030, achieve universal and equitable access to safe and affordable drinking water for all}

According to Table 1 in the previous section, urban India is close to meeting the target of universal coverage. However, there are several issues, including methodological concerns. ${ }^{4}$

What is 'safe' drinking water? Improved sources of water include piped water supply and safe ground water sources like covered wells, handpumps and borewells. There is increasing reportage (even though systematic data may be missing) of ground water in many urban areas being contaminated. This issue is pertinent given that a substantial number of households (45 per cent) do not treat their drinking water.

\footnotetext{
${ }^{4}$ Data collected for Census 2011 distinguished between treated and untreated tap water, and covered and uncovered wells. Only treated tap water and covered wells were counted as improved water sources.
} 
About 60 per cent of urban India is connected to piped municipal supply, which is generally considered to be at the top of the water improvement ladder. However, there is evidence of contamination of this water too, especially given the intermittent supply regime.

The Ministry of Urban Development's (MoUD) Service Level Benchmarking (SLB) exercises in 2010 showed that adequate water was not being supplied, and that many households were dependent on multiple sources of water. Can a combination of these be considered safe?

Some studies in urban India have also shown that poor households pay far more to buy water than other households who have access to cheap municipal water supply. Will they be counted equally as having access?

The urban-rural continuum further poses the challenge of improving access quickly enough to keep pace with the rapid urbanisation that different parts of India are witnessing.

\section{4: By 2030, substantially increase water-use efficiency across all sectors and ensure sustainable withdrawals and supply of freshwater to address water scarcity and substantially reduce the number of people suffering from water scarcity}

There is a great deal of variation in the policy instruments for achieving water efficiencies across different end-uses and sectors. Institutional gaps and divisions do not hold much promise on how water-use efficiencies can be achieved in a coordinated manner, for example, irrigation, industrial and domestic water use. While drinking water enjoys priority over other end-uses, this has not been without conflict and contestation. Moreover, the incentives for water conservation, re-use, etc., have not been strong enough to overcome institutional and sectoral fractures.

Even if we were to focus on municipal water systems, there are large operational inefficiencies: it is estimated that on an average, 45 per cent of water is non-revenue water. Contrary to popular belief, these losses are not just billing/commercial losses but also, in a large measure, physical losses. These physical water losses can be attributed to old, ageing infrastructure and lack of proper management of operations and maintenance (O\&M). As a result, Indian cities have to increasingly depend on surface water from distant sources or on excessive groundwater drawal. There is also concern over the excessive and indiscriminate use of water, at least by some sections of the society, highlighting the inequity in urban areas. India's rural drinking water guidelines have promoted the concept of water security but planning for water in urban India has been pre-occupied with supply-side augmentation solutions.

\section{2: By 2030, achieve access to adequate and equitable sanitation and hygiene for all and end open defecation, paying special attention to the needs of women and girls and those in vulnerable situations}

Urban India has made considerable progress in providing and improving access to sanitation facilities over the past three decades, and open defecation has reduced from 28 per cent in 1990s to 12 per cent in 2011 (JMP, Census 2011). The Swachh Bharat Mission (Urban) (SBM-U), with its focus on provision of toilets, is likely to bring this number down further. But are these toilets 'adequate' or 'improved'? Are they 'equitable'? 
Even as SBM-U addresses the issue of affordability by providing some incentives for household and community toilets, the target of 100 per cent access to sanitation is unlikely to be achieved because of the vexed problems of tenure security and space constraints faced by poor households. Moreover, the percentage of urban population that does not have access to individual household toilets, and hence needs to depend on public/community/shared toilets, is considerable. While some cities have succeeded in providing adequate and affordable community and public toilets, many, if not most of these toilets are ill-maintained and do not offer a sustainable option for changing sanitation practices.

The most important issue with regard to access to adequate sanitation is the safety of the containment structures. Census 2011 reports only a small percentage of existing structures as unsafe/unimproved. However, emerging evidence from different parts of India suggests that a considerable number of toilets are rendered unsafe because of poor design, construction and lack of proper maintenance /cleaning. This builds the case for correcting the estimate of households with adequate sanitation.

Besides, the current system appears inequitable because a large chunk of public investment has been directed towards sewerage systems and treatment systems, even as other households (including the urban poor) continue to pay more for the cleaning and maintenance of on-site systems.

As identified in the target, hygiene remains a key consideration. While hand-washing is recognised as a key indicator, there are other prevalent unhygienic practices, e.g., unsafe disposal of child faeces, unsafe water storage and handling practices, that are often not accorded importance.

The special needs of women and girls, and other vulnerable groups, have been acknowledged in policies and programme documents, but disaggregated data is not available except through case studies, etc. This poses considerable challenges in the monitoring and implementation of evidence-based strategies to address the needs of these target groups.

\section{3: By 2030, improve water quality by reducing pollution, eliminating dumping and minimizing release of hazardous chemicals and materials, halving the proportion of untreated wastewater and substantially increasing recycling and safe reuse globally}

The biggest deficit in urban sanitation is, of course, the dismal performance in waste water treatment. Anywhere between 80 and 90 per cent of waste water in urban India is let out untreated into the environment, causing considerable public health impacts (the economic impacts of which were estimated at $\square 2,180$ per capita per annum, the equivalent of about 6.4 per cent of India's GDP in 2006 (WSP, 2010).

Given urban India's poor record in treatment and its severe consequences, reducing the proportion of untreated wastewater only by half, by 2030 , seems grossly inadequate. This target needs to be made substantially higher for public health gains to start accruing to citizens. Full-cycle solutions may be achieved by networked systems in some of the larger cities, but in smaller cities, which are predominantly dependent on on-site systems, Faecal Sludge and Septage Management (FSSM) will be the appropriate value-for-money investment. 
A beginning has been made by including recycling and re-use as indicators in MoUD's SLB, as well as in the Round 1 Sanitation Rating of India's Class I cities (2010). However, no clear targets have been set, and there are no incentives for recycling.

Further, the issue of urban sanitation does not begin or end with access and treatment alone. Though not expressly formulated in the SDGs, if the desired outcome is improved public health, then the full cycle of urban sanitation must be secured, including safe and regular collection and conveyance. An increase in the number of treatment facilities is necessary, but there are other improvements required throughout the cycle-safe containment of and prevention of leakages of untreated excreta into the open, regular and safe emptying and desludging of septic tanks, a shift to mechanical equipment for emptying (preventing manual handling), safe conveyance, plugging of exfiltration in the sewerage networks, and so forth.

India has regulations for managing hazardous chemicals and wastes, and these are monitored by the Government of India and State Pollution Control Boards. The regulation and monitoring of these waste streams also need strengthening.

The most common approach to waste management in Indian cities has been to displace the pollutants and waste by dumping them into nearby peri-urban and rural areas. As greater citizens' awareness, judicial oversight and better enforcement have shown in many locations, urban India will need to rise to the challenge of planning and implementing waste management innovations using regional (urban-to-rural continuum) frameworks over the coming years.

\section{5: By 2030, implement integrated water resources management at all levels, including through trans-boundary cooperation as appropriate}

The framework for integrated water resources management in urban areas is non-existent. While water utilities and Urban Local Bodies (ULBs) plan the augmentation of water supply from far-off surface water sources, groundwater in and around cities remains unregulated, with considerable over-drawal along with reports of groundwater contamination. Some cities have adopted rainwater harvesting to conserve water and manage their limited resources better, but their impacts have been limited. Planning for wastewater is almost always an afterthought, most of the wastewater being released untreated (as described in the previous sections).

\section{6: By 2020, protect and restore water-related ecosystems, including mountains, forests, wetlands, rivers, aquifers and lakes}

Urban areas can substantially contribute to this target by achieving Targets 6.3 and 6. 4, i.e., by improving water efficiency and through waste water treatment. While the regulatory framework exists to prevent pollution of these ecosystems, enforcement and actual outcomes leave much to be desired. Certain isolated attempts aimed at prevention and restoration provide some indications on how these efforts can be scaled up. 


\section{Does the current policy framework respond to SDGs?}

India's policies have recognised the significance of urban water and sanitation for achieving public health improvements since the 2000s, resulting in a series of significant initiatives for water and sanitation. These initiatives have taken different forms-policies (e.g., National Urban Sanitation Policy 2008), programmes (JNNURM, Swachh Bharat Mission (SBM), Atal Mission for Rejuvenation and Urban Transformation or AMRUT, and other state level programmes), SLBs, advisories, guidelines and so on. Water and sanitation have seen increased visibility in public discourse and an increase in budgetary allocations (although rural water and sanitation have been accorded much higher priority owing to the huge deficits). Urban sanitation has received strong fillip from the current national government, the Swachh Bharat Mission (covering both rural and urban areas) being one of the flagship projects championed by the Prime Minister.

How successful have these been and will be in meeting the SDG targets in the future?

SBM-U and AMRUT are likely to have the most significant impact on the sector. These schemes address the SDG targets in the following ways:

- Water supply is one of the thrust areas under AMRUT, and this includes the augmentation and refurbishment of water supply systems. The scheme prioritises improvements in water supply for the first few years, and a number of cities have submitted proposals for the extension or refurbishment of water supply that should lead to improved service coverage.

- SBM-U provides grants for the construction of individual household toilets, as also viability gap funding for community and public toilets. It is not clear whether the Government of India grant of $\square 4,000$ will be sufficient incentive for the construction of individual toilets-some states and ULBs have provided their own supplementary grants to encourage households. SBM-U also encourages overcoming tenure issues (by having ULBs ensure regularisation and de-linking tenure from the grant), but its efficacy remains to be assessed.

- In addition to providing funds for the extension of networked systems, AMRUT also provides funds for septage management, making it the first national scheme to do so.

- $\quad$ AMRUT requires the preparation of Financial Operating Plans (FOPs) for the assets being created, thus increasing the potential sustainability of capital investments.

Several states, including Maharashtra and Tamil Nadu, have taken the initiative to promote septage management. In addition, Service Level Benchmarks, though not binding, highlight the importance of service levels and measuring outcomes. 
Hence, the current policy initiatives in urban India are beginning to address some of the SDG targets on improving drinking water and sanitation, but several gaps remain to be addressed.

SBM-U covers all statutory urban areas $(4,041)$, but only 500 cities are eligible for AMRUT funding. Prior to AMRUT, JNNURM had funded only 68 large and important cities. The only sources of funding available for the smaller towns and cities have been state government schemes, which are not adequate.

Namami Gange, a national programme, attempts to address the issue of river conservation but, as with similar programmes in the past, there are major gaps in linking investments to ULB level infrastructure and systems.

Table 4 presents the current status and future prospects of generating evidence for key SDG indicators.

\section{Table 4: Availability of Data for SDG Indicators}

\begin{tabular}{|c|c|c|c|}
\hline No. & SDG Indicators & Existing Framework & $\begin{array}{l}\text { Recommendations } \\
\text { and Prospects }\end{array}$ \\
\hline 1 & $\begin{array}{l}\text { 6.1.1 Proportion of } \\
\text { population using safely } \\
\text { managed drinking } \\
\text { water services }\end{array}$ & $\begin{array}{l}\text { Census and NSSO data provide } \\
\text { information on source of drinking } \\
\text { water, Service Level Benchmarks on } \\
\text { service provisioning level } \\
\text { Limited data on water quality_and } \\
\text { water safety } \\
\text { No information on management } \\
\text { practices }\end{array}$ & $\begin{array}{l}\text { Determine } \\
\text { frequency and scale } \\
\text { Decentralise to } \\
\text { states and ULBs } \\
\text { Role of media and } \\
\text { citizens' groups in } \\
\text { collecting and } \\
\text { disseminating data }\end{array}$ \\
\hline 2 & $\begin{array}{l}\text { 6.2.1 Proportion of } \\
\text { population using safely } \\
\text { managed sanitation } \\
\text { services, including a } \\
\text { hand-washing facility } \\
\text { with soap and water }\end{array}$ & $\begin{array}{l}\text { The data on type of containment } \\
\text { structures is collected through } \\
\text { Census-no information on actual } \\
\text { design, performance and collection } \\
\text { practices. } \\
\text { No information on availability of } \\
\text { hand-washing facility or other } \\
\text { hygiene indicators }\end{array}$ & $\begin{array}{l}\text { New sources of } \\
\text { data } \\
\text { Or augmenting } \\
\text { existing data } \\
\text { collection systems? }\end{array}$ \\
\hline 3 & $\begin{array}{l}\text { 6.3.1 Proportion of } \\
\text { wastewater safely } \\
\text { treated } \\
\text { 6.3.2 Proportion of }\end{array}$ & $\begin{array}{l}\text { Various state government and ULBS } \\
\text { records have information on } \\
\text { treatment facilities } \\
\text { Data on amount of waste water }\end{array}$ & $\begin{array}{l}\text { Needs proper } \\
\text { compilation and } \\
\text { analysis }\end{array}$ \\
\hline
\end{tabular}




\begin{tabular}{|c|c|c|c|}
\hline No. & SDG Indicators & Existing Framework & $\begin{array}{l}\text { Recommendations } \\
\text { and Prospects }\end{array}$ \\
\hline & $\begin{array}{l}\text { water bodies with good } \\
\text { ambient water quality }\end{array}$ & $\begin{array}{l}\text { treated is available with Pollution } \\
\text { Control Board } \\
\text { The Pollution Control Board collects } \\
\text { data for limited stretches }\end{array}$ & \\
\hline 4 & $\begin{array}{l}\text { 6.4.1 Change in water } \\
\text { use efficiency over time } \\
\text { 6.4.2 Level of water } \\
\text { stress: freshwater } \\
\text { withdrawal as a } \\
\text { proportion of available } \\
\text { freshwater resources }\end{array}$ & $\begin{array}{l}\text { Service Level Benchmarks for select } \\
\text { ULBs } \\
\text { No data available }\end{array}$ & $\begin{array}{l}\text { New indicators? } \\
\text { Method of data } \\
\text { collection? }\end{array}$ \\
\hline 5 & $\begin{array}{l}\text { 6.5.1 Degree of } \\
\text { integrated water } \\
\text { resources management } \\
\text { implementation } \\
\text { 6.5.2 Proportion of } \\
\text { trans-boundary basin } \\
\text { area with an } \\
\text { operational } \\
\text { arrangement for water } \\
\text { co-operation }\end{array}$ & No data available & $\begin{array}{l}\text { A separate } \\
\text { indicator for urban } \\
\text { Integrated water } \\
\text { resources } \\
\text { management } \\
\text { needed }\end{array}$ \\
\hline 6 & $\begin{array}{l}\text { 6.6.1 Change in the } \\
\text { extent of water-related } \\
\text { ecosystems over time }\end{array}$ & $\begin{array}{l}\text { Data and inventories limited or } \\
\text { available in disparate locations }\end{array}$ & $\begin{array}{l}\text { Data needs to be } \\
\text { collected/analysed } \\
\text { for urban areas }\end{array}$ \\
\hline
\end{tabular}




\section{Institutional Arrangements and Financing Mechanisms: Who will implement and monitor?}

Under the Indian Constitution, state governments are responsible for provision of drinking water and sanitation in both rural and urban areas. In 1994, with the $74^{\text {th }}$ Constitutional Amendment, water and sanitation were further devolved to ULBs. In practice, however, much of the locus of decision making lies with the union and state governments. The Government of India has had considerable influence on the sector through two mechanisms: the design of Centrally Sponsored Schemes (CSSs), which are the main source of investment in the sector, and by establishing technical standards, norms and processes through manuals and guidelines.

State governments have typically been responsible for technical proposals and the implementation of approved projects under CSSs, and for the execution of their own state schemes. There have been some changes in the case of AMRUT, whereby some of the decision making has shifted to the state level, but it is only with respect to the technical sanction of projects; overall programme management and monitoring is still under the Government of India. Within the states, the role of most ULBs usually begins once the assets have been created, following which they are responsible for service provision and O\&M of assets. In metropolitan or large cities, a division of the ULB or a separate utility may be responsible for the design and implementation of infrastructure.

The ULBs that are responsible for achieving most of the targets (6. 1 to 6.4) do not have sufficient capacities or skills to implement these targets and will have to depend on the union and state governments to fulfil their responsibilities. The primary mechanism for achieving most of these targets is through the implementation of national flagship schemes, supplemented with state schemes where those exist, both to increase coverage and for the creation of additional infrastructure. ${ }^{5}$ ULBs will need to be strengthened considerably to take on the responsibilities of service delivery, O\&M management, etc., on a sustainable basis.

In the case of water supply, increased investments are needed not only to augment supply through conservation and recharge measures but most importantly, in improving efficiencies of distribution management, which has been the death-knell of water supply systems in most Indian cities.

With respect to sanitation, urban India needs to considerably increase its treatment capacity for waste water and for faecal sludge. While it is less expensive to focus on septage management it is not certain where the finances required even for such value-for-money investments can be sourced. Government funding is not likely to be sufficient, and only some states have the fiscal capacity to supplement these investments. The preparation of FOPs

${ }^{5}$ The mapping of responsibilities by Niti Aayog focusses primarily on rural areas for SDGs. 
under AMRUT is not an adequate measure to address the severe financial and capacity deficits of ULBS.

\section{Conclusion}

SDG 6 and its targets represent a substantial improvement over the targets laid out in the MDGs, as SDG 6 goes beyond the question of access, having put forth a more holistic framework. Some of this is also reflected in India's policies.

Certain aspects of SDG 6, including conceptual concerns around the framing of certain targets, remain to be addressed. There are several gaps in reaching the SDG targets, and India's current programmes only address a few of these. India will need to adapt the frameworks of its urban water and sanitation flagship programmes in order to meet the SDG 6 targets and its own policy goals, while ensuring proper monitoring of progress. 



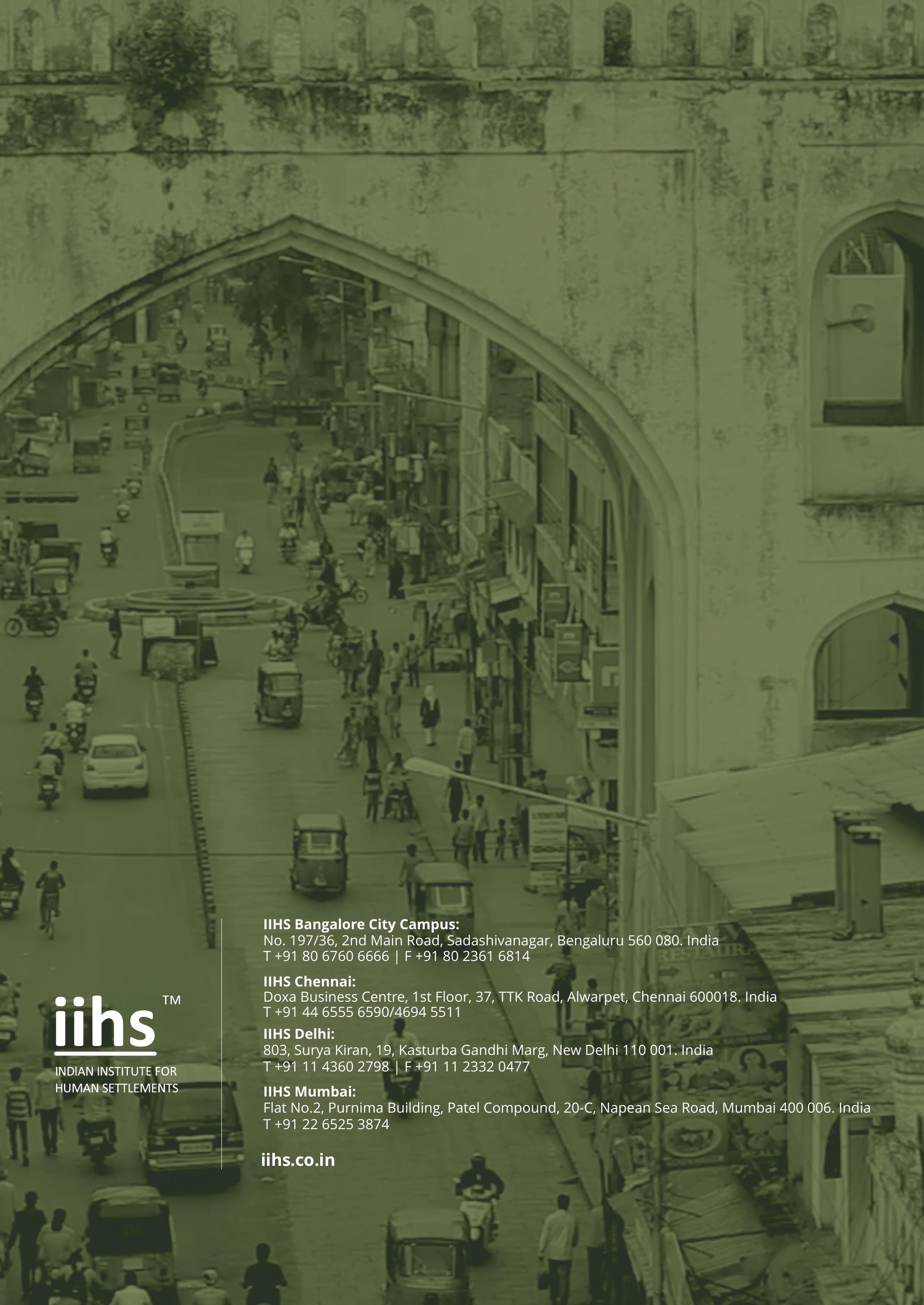




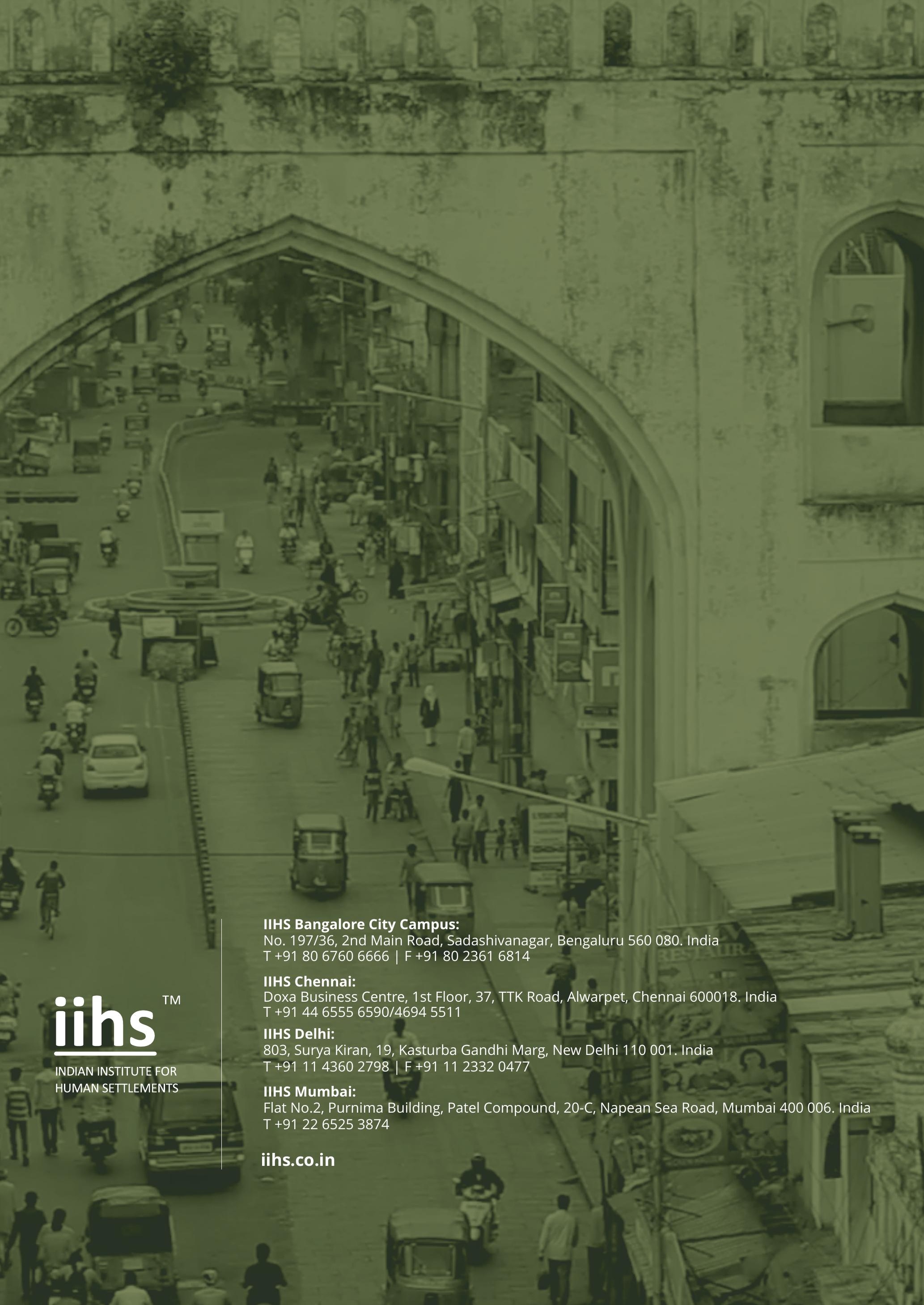

